シリコン注入例に対する甲状軟骨形成術

森 一功・富田 和英・中島 格

\title{
Thyroplasty Type I after Transcutaneous Intrafold Silicone Injection
}

\author{
Kazunori Mori, Kazuhide Tomita and Tadashi Nakashima \\ (Kurume University School of Medicine)
}

\begin{abstract}
Three cases, who underwent Isshiki Thyroplasty type I, because their vocal function had not improved with a previous transcutaneous intrafold silicone injection, were reported. Their poor outcomes with previous treatment were thought to result mainly from an insufficient volume of injected silicone and/or an inappropriate portion of silicone in the larynx.

In all three cases, the so-called manual compression test of the thyroid cartilage ala preoperatively revealed drastic improvement of their voice. During operation, however, their vocal fold tissues were too stiff to medialize the vocal fold, resulting in poor postoperative vocal function in first two cases. Based on these results, in the third case the inner perichondrium was raised more widely than usual and a larger silicone block was inserted with removal of the cartilage fragment, resulting in a moderate improvement in vocal function.

It seems that after intrafold silicone injection fibrotic changes may occur widely in the vocal fold tissue histopathologically, causing subsequent difficulty in medialization of the vocal fold by the usual Isshiki Thyroplasty type I .
\end{abstract}

Key words : transcutaneous intrafold silicone injection, Thyroplasty type I, vocal function

緒 言
当院では片側の声帯麻痺の音声改善のために声帯内シ
リコン注入を行ってきた. 注入の方法については既に詳 細に報告されている12)ので割愛する。その成績につい ては, 他覚的には最長持続発声時間 (MPT), 平均呼気 流率 (MFRc), 声の高さ域 (FOrange), 声の強さ域 (SPLrange), 基本周期変動率 $(\mathrm{PPQ})$, 最大振幅変動率 (APQ), 規格化雑音エネルギー $(\mathrm{NNEa})$ はすべて改善し, 自覚的 には正常化が $40 \%$, 改善が $56 \%$ で，不変は $4 \%$ であり， 音声の悪化を訴えた者は 1 例もないことを報告した22. すなわち, シリコン注入術は外来で施行可能な, 安全か つ簡便な手技であり，有効な治療法であると言光る.

一方で, 注入用シリコンは乳ガンの発生との関係3が
指摘され, 現在では高研のエリコンヤングは販売中止と なり，富士システムのファイコンも入手できなくなった。 そのため当院でも, ここ 1 年程前から,一側声帯麻痺に 対するシリコン注入術の適応を大幅に限定し, 食道癌の 姑息切除術後のような予後の悪い患者に対してのみ, QOL を改善させるためにシリコン注入を行うようにし ている. そして予後の良好な患者に対しては積極的に甲 状軟骨形成術) や披裂軟骨内転術5)を勧めている. 今回, シリコン注入を行っても嗄声が改善しなかった 3 症例に 対して, シリコンの再注入のかわりに甲状軟骨形成術を 施行した．その治療結果を報告するとともに，今後の反 省としたい。 


\section{症例}

\section{症例 164 歳, 男性.}

1995年 7 月 6 日に某医で甲状腺右葉切除, 縦隔内腫瘍 切除を受けた。病理組織は腺腫様腺腫であった。 反回神 経は保存したとのことであるが，術直後より嗄声が生じ た。右声帯は副正中位に固定し，発声時に著明な声門間 隙を認めた(図 1)，筋電図では発声時に低電位ながら筋 放電を認めたので，経過観察とした。しかしその後も声 帯運動は改善しないため，1996年 2 月 6 日右声帯にシリ コンを注入した。注入後 3 日はきわめて良好な声だった がその後次第に悪化し，注入から 1 週間後には元に戻っ てしまったという（表 1)。その後経過を観察していたが，

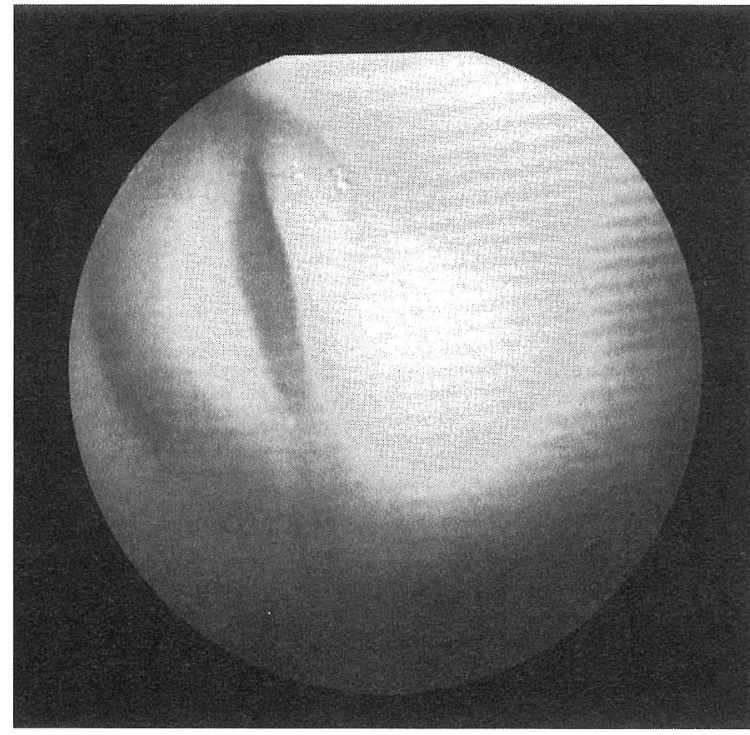

図 1 症例 1 のシリコン注入前の発声時の喉頭像 右声帯(図のむかって左)は副正中位に固定し弓状となっ ている.
再度患者の希望により，1996年11月 6 日甲状軟骨形成 I 型を施行した。手術直前の発声時の声帯像(図 2 )では, シリコン注入前と声門間隙の程度はあまり变わらなかっ た。また，手術前の喉頭の CT (図 3 )では, シリコンは 声帯の後方に少量入っているだけであった。

手術は一色の方法 ${ }^{4)}$ に従って甲状軟骨に開空した。内 軟骨膜を剥離したが声帯は極めて硬くて内方へほとんど 変位しなかった，甲状軟骨の厚さプラス $2 \mathrm{~mm} の$ 厚さの シリコンブロックで開密部の軟骨片をそのまを押し込み 固定したが,手術後も音声はほとえど改善しなかった(表 1 ).

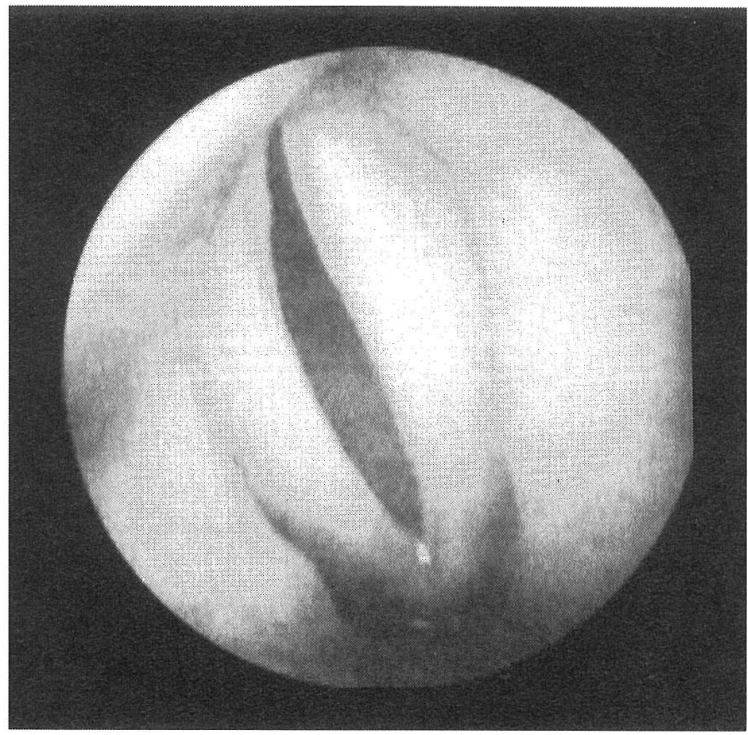

図 2 症例 1 の手術直前(シリコン注入後約 9 カ月)の発声時の 喉頭像

右声帯(図のむかって左)は注入前と同じく，副正中位に 固定し弓状となって括り，著明な声門間隙を認める。

表 1 症例 1 の音声機能の変化

\begin{tabular}{c|c|c|c|c|c|c|c}
\hline \hline & $\mathrm{MPT}$ & $\mathrm{MFR}$ & FO range & SPL range & $\mathrm{PPQ}$ & $\mathrm{APQ}$ & $\mathrm{NNEa}$ \\
\cline { 2 - 8 } & $\mathrm{sec}$ & $\mathrm{ml} / \mathrm{sec}$ & semitone & $\mathrm{dB}$ & $\%$ & $\%$ & $\mathrm{~dB}$ \\
\hline シリコン注入前 & 2.7 & 513 & 15 & 32 & 5.56 & 22.50 & -3.7 \\
\hline 注入後 & 3.3 & 421 & 14 & 28 & 1.79 & 6.00 & -11.5 \\
\hline 手術直前 & 2.2 & 353 & 19 & 35 & 1.44 & 4.54 & -10.8 \\
\hline 手術後 & 2.6 & 454 & 17 & 24 & 1.85 & 11.00 & -8.4
\end{tabular}




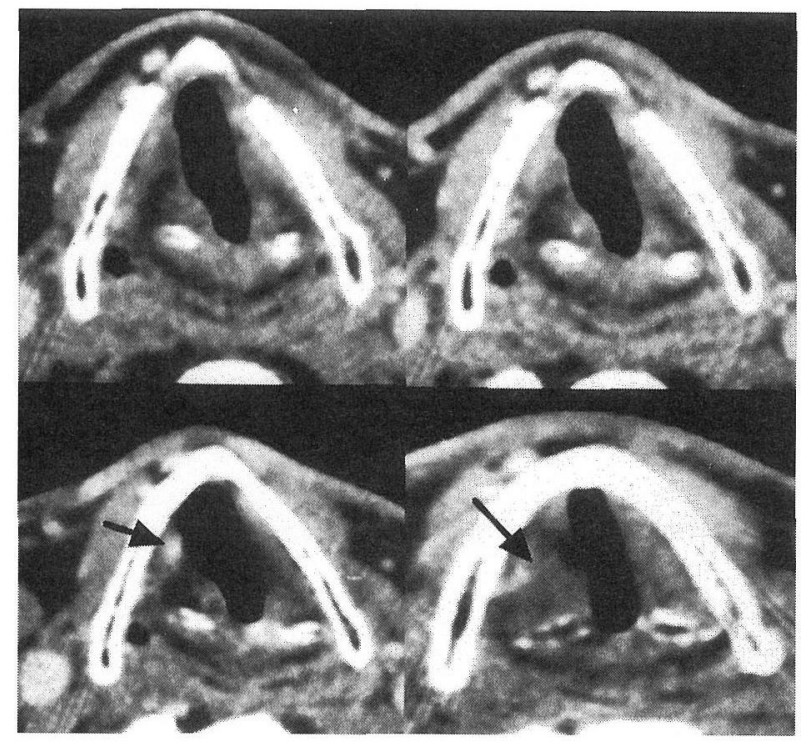

図 3 症例 1 の手術直前の CT 像

声帯後方にわずかにシリコンが残っている(矢印).

症例 2 58歳, 男性.

1992年10月 9 日に当院で甲状腺乳頭癌の診断で甲状腺 全摘，両側頸部郭清を施行．この際右反回神経を切断し た．右声帯は副正中位に固定し，発声時に著明な声門間 隙を認めた(図 4 )。患者の希望で1993年 8 月 4 日シリコ ソを注入したが，その際，頸部皮膚が瘦痕状できわめて 硬くて輪状甲状間隙の部位がわかりにくかった。そのた め，注入針の先端部を声帯突起外側に持ってくる時の才 リエンテーションをつけるのが非常に難しかった。注入 により声帯位は汪とんど変わらず，音声の改善はごく軽 度であった(表 2 )。 その後, 音声が悪化して生活に支障 を来すよらになってきたため，1997年 4 月 2 日甲状軟骨 形成 I 型を施行した。手術前の発声時の喉頭像(図 5 )は

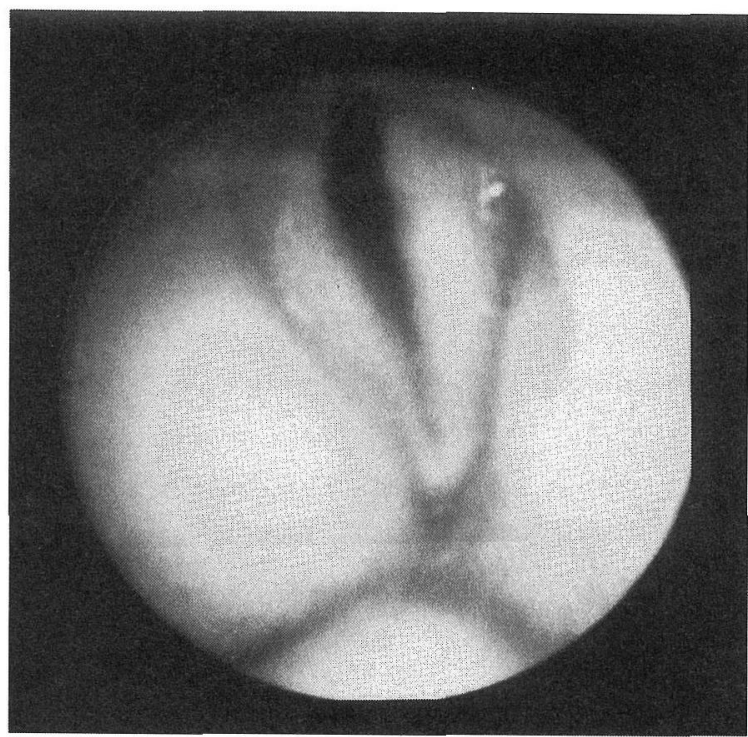

図4 症例 2 のシリコン注入前の発声時の喉頭像 右声帯(図のむかって左) は副正中位に固定し，声門間隙 が著明である。

シリコン注入前と汪とんど変わらず，手術前の喉頭 CT (図 6)でも，シリコンの所在は明らかではなかった。当 初，手術は披裂軟骨内転術を予定していたが，頸部皮膚 の瘢痕が極めて強いこと，頸部郭清術を行っていて総頸 動脈が甲状軟骨のすぐそばへと変位していることから断 念した．甲状軟骨に開空して軟骨膜を剥離したが声帯は 極めて硬くて内方への変位はわずかであった．甲状軟骨 の厚さプラス $2 \mathrm{~mm}$ の厚さのシリコンブロックで開公部 の軟骨を执しこみ，固定した。手術後の音声は軽度改善 に留まった(表 2$)$ が，MPT が 6 秒台となって仕事の支 障は法とんどなくなったとのことである。

表 2 症例 2 の音声機能の变化

\begin{tabular}{c|c|c|c|c|c|c|c}
\hline \hline & $\mathrm{MPT}$ & $\mathrm{MFR}$ & FO range & SPL range & PPQ & $\mathrm{APQ}$ & $\mathrm{NNEa}$ \\
\cline { 2 - 8 } & $\mathrm{sec}$ & $\mathrm{ml} / \mathrm{sec}$ & semitone & $\mathrm{dB}$ & $\%$ & $\%$ & $\mathrm{~dB}$ \\
\hline シリコン注入前 & 4.2 & 547 & 7 & 18 & 0.61 & 9.35 & -7.7 \\
\hline 注入後 & 6.2 & 593 & 8 & 23 & 1.23 & 9.12 & -12.8 \\
\hline 手術直前 & 2.6 & 762 & 9 & 20 & 0.36 & 7.41 & -10.4 \\
\hline 手術後 & 6.5 & 305 & 14 & 30 & 0.20 & 1.03 & -24.2
\end{tabular}




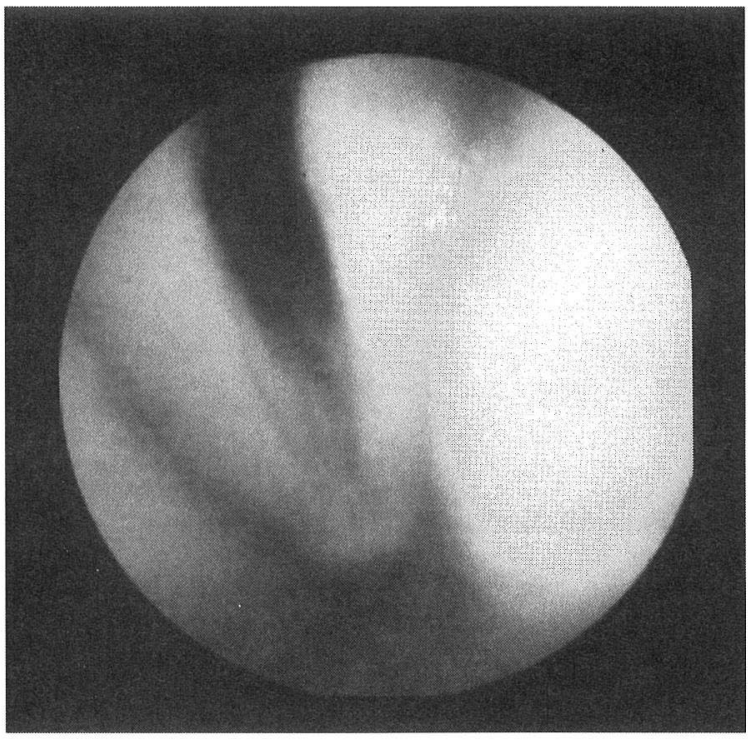

図 5 症例 2 の手術直前 (シリコン注入後約 3 年半)の発声時の 喉頭像

右声帯(図のむかって左) は同じく副正中位に固定し，声 門間隙が著明である。

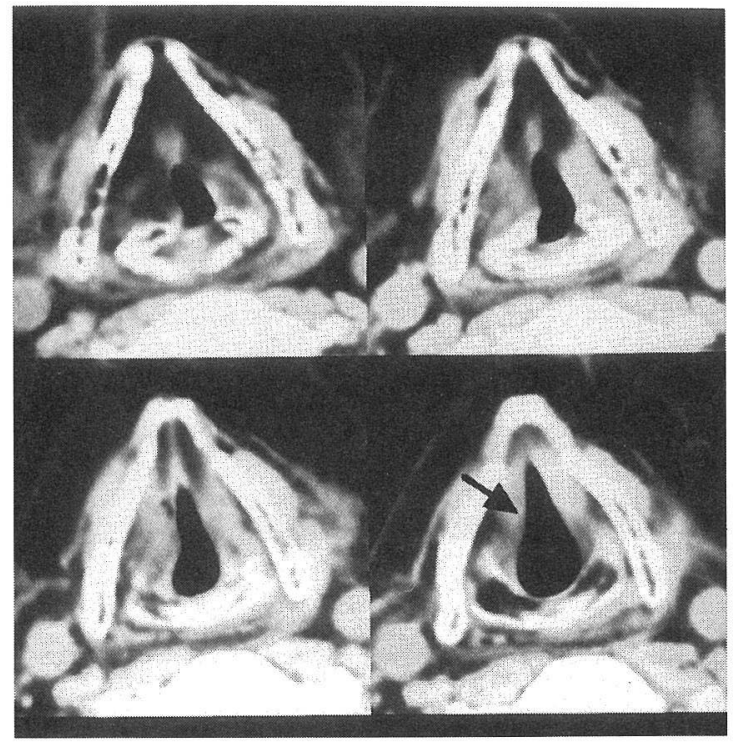

図 6 症例 2 の手術直前の $\mathrm{CT}$ 像 声帯内のシリコンは明らかではない(矢印).

症例 3 77歳, 男性.

1996年 1 月16日に某医で甲状腺癌の診断で甲状腺巠全 摘を受けた。この時左反回神経を切断したとのことであ

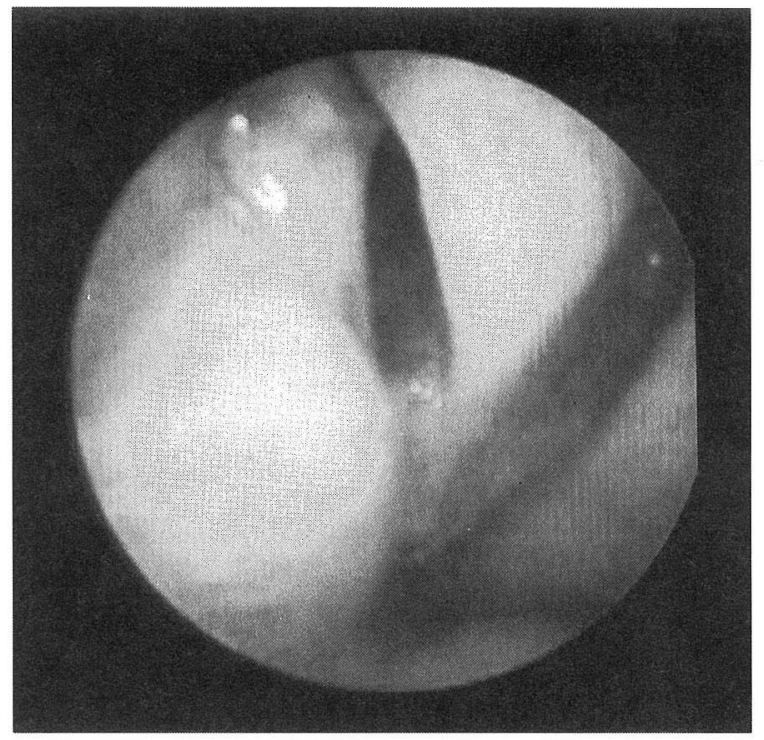

図 7 症例 3 のンリコン注入前の発声時の喉頭像 左声帯(図のむかって右)は固定し，発声時の大きな声門 間隙と声帯の上下のレベル差が著明である.

る．左声帯は中間位に固定し，発声時には大きな声門間 隙と声帯の上下のレベル差を認めた(図 7 )。1996年12月 4 日に左声帯にシリコンを注入した。注入により軽度改 善を認めた(表 3 )が，その後次第に声は悪化した。半年 後には注入前よりも悪化した(表 3 )ので1997年 7 月 2 日 に甲状軟骨形成 I 型を施行した. 手術直前の声帯所見(図 8 )では，レベル差は矯正されているが，やはり発声時 の声門間隙を認めた。また，両側に浅い声帯溝症を認め た。CT (図 9)では左声帯よりもやや下方にシリュンが 留まっていた。

甲状軟骨に開空したが症例 1 と 2 と同じく, 声帯の内 方移動は硬くて難しく、シリコンブロックを挿入しても 音声は全く変化しなかった．そこで症例 1 と 2 の経験に 基づき，軟骨膜をできるだけ広範囲に，つぬり開空部の 空枠から約 $5 \mathrm{~mm}$ 以上剥離した。これにより声帯はかな り内方へ変位するようになった。ついで開空部の甲状軟 骨片を除去して，厚さ $3 \mathrm{~mm}$ のンリコンブロックを声帯 仮声帯全体が内方へ移動するように挿入し，固定した。

手術後の MPT は約10秒となり，患者は満足している.

考案

一側性反回神経麻疾に対する音声改善手術は種々報告 されている144)77. 当科では声門間隙が小さい時には経 
表 3 症例 3 の音声機能の変化

\begin{tabular}{c|c|c|c|c|c|c|c}
\hline \hline & MPT & MFR & FO range & SPL range & PPQ & APQ & NNEa \\
\cline { 2 - 8 } & $\mathrm{sec}$ & $\mathrm{ml} / \mathrm{sec}$ & semitone & $\mathrm{dB}$ & $\%$ & $\%$ & $\mathrm{~dB}$ \\
\hline シリコン注入前 & 7.5 & 376 & 測定不能 & 19 & 測定不能 & 測定不能 & 測定不能 \\
\hline 注入後 & 8.9 & 333 & 測定不能 & 29 & 測定不能 & 測定不能 & 測定不能 \\
\hline 手術直前 & 3.2 & 483 & 16 & 40 & 0.88 & 5.55 & -18 \\
\hline 手術後 & 9.9 & 307 & 20 & 34 & 0.42 & 4.92 & -14.2
\end{tabular}

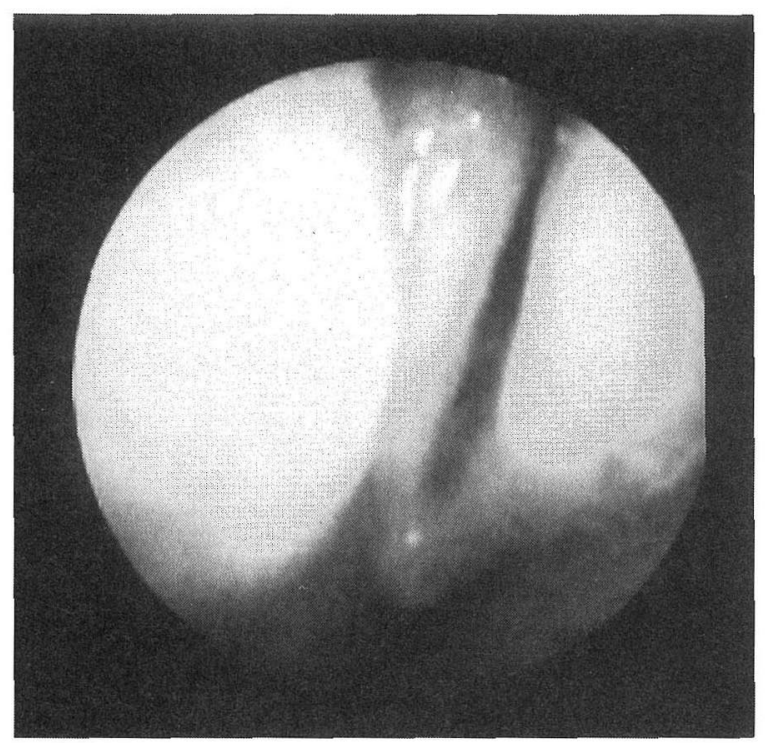

図 8 症例 3 の手術直前(シリコン注入後約 7 カ月)の発声時の 喉頭像

図 7 に比べて, 声帯の上下のレベル差は矯正されている が，やはり声門間隙が認められる.

皮的シリコン声帯注射を第一選択として行い，間隙が大 きなときには披裂軟骨内転術を行った後に必要に応じて シリコン注射を追加してきた2). 重篤な副作用や発癌は 今までのところ認められていない2288.

問題はシリコン注入で良好な結果を得られなかった場 合である。これは頻度的には少ない22が，対応が難しい。 良好な結果が得られない原因としては, 広範な頸部手術 後などで前頸部に㓔痕化が顕著な時や，輪状甲状間隙が 狭い時，反射が強すぎる時などが報告されている11. ま た，声帯溝症を伴う場合は成績が不良であり，注入直後 の声帯の膨隆度が大さな影響を与劣をとされる91。そこ で本症例を振り返ってみると, 症例 1,2 は注入量が少

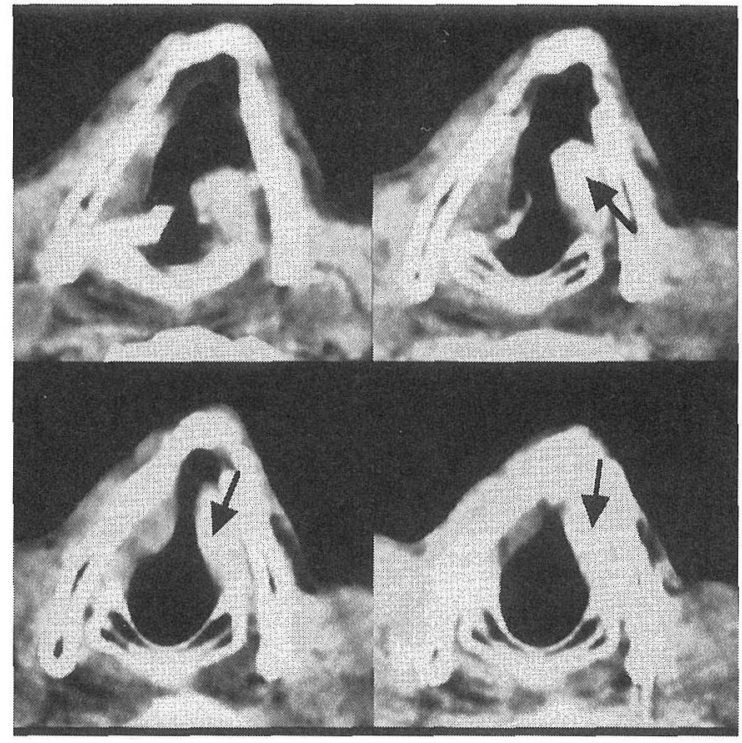

図 9 症例 3 の手術直前の CT 像 声帯よりやや下方にシリコンが入っている(矢印).

なかったと推察される.症例 1 は注入時に内出血を扢こ し，そのために声帯が充分膨隆したかに見卞，音声は改 善した。しかしこの出血が 1 週間注どで吸収され，体積 が減少して元の声に戻ったのではないかと考光ている。 症例 2 は前頸部に瘢痕化が顕著なため, 注入針の針先の オリエンテーションをつけるのが非常に難しく，そのた め, 充分な量のシリコンが注入されなかったと考兵られ る. CT 上, 症例 3 に比べると症例 1,2 ではシリコン の陰影が少ないことはこの考劣を裏付ける．症例 3 では $\mathrm{CT}$ 上, シリコンは充分入っているが位置がやや低いこ とと, 声帯溝症が認められたことが原因と考光られる. また，注入後に急速に音声機能が悪化した理由としては, 加齢により声帯萎縮が進んだことが関係するかもしれな 
い.

このよらなシリコン注入後に音声が改善しなかった場 合に甲状軟骨形成術を追加したといら報告は少なく10)， その詳細は明らかではない。当科では多くの場合はシリ コンを追加注入することで扮持むね良好な結果を得てき ている11)。しかし，その手技は初回注入に比べて難しい といら印象がある.さらに，上述のように当科でも注入 用シリュンの使用そのものを制限しつつある。そのため 今回はシリコンの再注入のかわりに甲状軟骨形成術を行 った。もちろん，挿入したのが同じくシリコンであるか ら，生体への影響などの問題がないわけではないと考光 られるので，今後はアパタイトブロックの使用12)を考 えている.

甲状軟骨形成術を行った際の術中所見として 3 例とも に見られた喉頭の特徴は，内軟骨膜をはがしても声帯が 硬くて内方に変位しにくいことであった．そのため， 3 例とも術前の甲状軟骨のいわゆる圧迫テスト (manual test)ではかなりの改善を認めたにもかかわらず，結果 は良好ではなかった。喉頭に注入されたシリコンの組織 学的検討8)13) 15) によると，炎症細胞は医とんどなく， 線維性結合組織で括执われてしまうとされる。本症例で も，このような繊維化が声帯执よびその周囲組織に広範 囲に生じたか，あるいはシリコンが結合組織で声帯内に 硬く固定されたことが考えられる．とのため，症例 3 で は内軟骨膜をきわめて広範囲に剥離した。 さらに声帯レ ベルだけの内方移動は諦めて，開空部の軟骨片を除去し て声帯仮声帯全体が大きく内方へ移動するようにシリコ ンブロックを挿入した．軟骨片を除去したのは，やや下 方に入っているシリコンが軟骨片による圧迫で予期せぬ 方向へ変位するのを恐れたからで，軟骨片除去により注 入されたシリコン塊が変位しやすくなったといら印象は なかった。いずれにせよこの手技により，症例 $1 ， 2$ よ りも良好な術後音声機能を得ることができた.

以上より, シリコン注入後の音声不良の原因は症例 1 , 2 では注入量不足, 症例 3 では注入シリコンの位置不良 で原因が異なることから，一般的な結論は避けねばなら ないが，いずれにせよ，当科でのシリコン注入の手技で は注入後には声帯レベルを内方へ移動させようとするの は難しいことがわかった。このような場合，内軟骨膜を 大きく剥離して声帯仮声帯全体を大きく内方移動させる ことも一つの方法であると考えられた.

\section{まとめ}

一側性声帯麻痺症例に対して, 経皮的固化型シリコン 注入を行っても音声の改善の得られなかったため甲状軟 骨形成術を行った 3 症例を報告した. 声帯全体が硬くて 内方へ移動させるのが困難なため，良好な成績は得られ なかった。このような症例に対しては, 内軟骨膜を広範 囲に剥離して声帯仮声帯を全体として内方移動させる必 要があると考えられた。

\section{参考文献}

1) Hirano M, Tanaka S, Tanaka Y, et al : Transcutaneous intrafold injection for unilateral vocal fold paralysis ; functional results. Ann Otol Rhinol Laryngol 99 : 598 604, 1990.

2 ) 森 一功, 平野 実, 藤田真知子: 一側性声帯麻盘に対す る経皮的固化型シリコン声帯注射. 耳鼻臨床 $88: 12 \sim 14$, 1995.

3 ) Maddox A, Schoenfeld A, Sinnett HD, et al : Breast carcinoma occuring in association with silicone augmentation. Histopathology $23: 379 \sim 382,1993$.

4 ) Isshiki $\mathrm{N}$, Okamura $\mathrm{H}$ and Ishikawa $\mathrm{T}$ : Thyroplasty type I (lateral compression) for dysphonia due to vocal cord paralysis or atrophy. Acta Otolaryngol (Stockh) $80: 465$ $\sim 473,1975$.

5 ) Isshiki N, Tanabe M and Sawada M : Arytenoid adduction for unilateral vocal cord paralysis. Arch Otolaryngol $104: 555 \sim 558,1978$.

6 ) Ford $\mathrm{CN}$ and Bless DM : Clinical experience with injectable collagen for vocal fold augmentation. Laryngoscope $96: 863 \sim 869,1986$.

7 ) Brandenburg JH, Kirkham W and Koschkee D : Vocal cord augementation with autogenous fat. Laryngoscope $102:$ 495 500, 1992.

8 ) Tsuzuki T, Fukuda $\mathrm{H}$ and Fujioka $\mathrm{T}$ : Response of the human larynx to silicone. Am J Otolaryngol $12: 288 \sim 291$, 1991.

9 ) 田中信三, 平野 実, 田中康政, 他 : 経皮的声帯内注射の 治療成績とその影響因子について．日耳鼻 $94: 817 〜 822$, 1991.

10）牛島達次郎：声帯内シリコン注入症例に対する再手術の検 討. 音声言語医学 $24: 92 \sim 93,1983$.

11) Hirano $M$, Mori $K$, Tanaka $S$, et al : Vocal function in patients with unilateral vocal fold paralysis before and after silicone injection. Acta Otolaryngol (Stockh) $115: 553 \sim$ 559, 1995.

12) Cummings CW, Purcell LL and Maryland B : Hydroxylapatite laryngeal implants for medialization; preli- 
minary report. Ann Otol Rhinol Laryngol $102: 843 \sim 851$, 1993.

13）福田宏之：注入用 Silicone とよるVocal Rehabilitation. 日耳鼻 $73: 1506 \sim 1526,1970$.

14）岩村 忍, 竹内貴志子 : 片側反回神経麻痺に対するシリコ 乙注入療法. 日気食会報 $35: 17 \sim 27,1984$.

15）大沢弘明: 声帯内注射潦法汇関する研究. 耳鼻 $24: 233 \sim$ 251, 1978.
原稿受付: 平成 9 年 8 月 11 日 原稿採択: 平成 9 年 9 月 3 日 別刷請求先 : 森 一功 于830-0011 久留米市旭町67

久留米大学医学部耳鼻咽喉科学教室 